\title{
FEATURES OF THE ORGANIZATION OF FOREIGN LANGUAGE CLASSES BASED ON A META-SUBJECT APPROACH
}

\author{
Aruzhan Sattarova ${ }^{1}$, Natalya Ustelimova ${ }^{2}$ \\ ${ }^{1}$ L.N. Gumilyov Eurasian National University \\ ${ }^{2}$ L.N. Gumilyov Eurasian National University
}

ORCID ID: 0000-0002-2849-8926

\begin{abstract}
«... the child draws what is available to him and the means that he owns, therefore, the culturally richer the environment of the child, the more he creates incentives to master more complex cultural means and allows him to use this environment more widely»
\end{abstract}

Blonsky P.P.

\begin{abstract}
The ability to overcome life collisions, the ability to find new, non-standard solutions to problems these qualities are relevant in the modern world. Changes in society entail changes in the upbringing of schoolchildren, and this is due to the individual, personal and professional qualities of a teacher, such as: organization, increased self-esteem and professional competence, focus on results. The level of development of children's creativity, their readiness to study at school and for life, also depends on the professionalism of teachers. It is the teacher, as a universal specialist, who, when planning and organizing classes in different subjects, is able to identify characteristic subject relationships, determine the necessary means of teaching and development of schoolchildren, and also design identical results of educational activities in several educational areas. Meta-subject approach is a means of achieving a meta-subject result. The main goal of the meta-subject approach in teaching is: the development and qualitative renewal of pedagogical activities, and the improvement of the quality of education.
\end{abstract}

The meta-subject approach in teaching contributes to the retreat of practice, when the teacher works frontally with the whole class. With this approach in teaching, individual and group forms of work in the lesson are more often organized. The authoritarian style of communication between teacher and student is gradually overcome. I agree with Bernard Shaw, who expressed the correct thought: "The only path leading to knowledge is activity!" To make this activity more effective, I am constantly looking for effective methods and forms of training. In my practice I use elements of problematic, search, research. To ensure positive meta-subject results of the activity with students of non-linguistic specialties of the 1st year students in the context of modernization of education, I use a meta-subject lesson. A meta-subject lesson is understood as "The teacher's organization of the student's independent mental activity for the qualitative mastering of the useful content of the educational material for a certain time." In this definition, S.S. Tatarchenkova should pay attention to the fact that the student masters the educational material independently and in the process of activity, and the task of the teacher is to organize this activity. Thus, the goals, content, requirements for the results of educational activities have changed significantly in the light of the new standard.

The modern lesson, while retaining its structure, has significantly changed the content and organizational content of the usual stages.

Table 1. Lesson stages

\begin{tabular}{|c|c|c|}
\hline $\begin{array}{c}\text { Requirements for the } \\
\text { organization of the } \\
\text { lesson }\end{array}$ & Traditional lesson & Modern type lesson \\
\hline
\end{tabular}




\begin{tabular}{|c|c|c|}
\hline $\begin{array}{l}\text { Announcement of the } \\
\text { topic of the lesson }\end{array}$ & Teacher informs students & $\begin{array}{l}\text { Students themselves formulate (the } \\
\text { teacher leads students to understand } \\
\text { the topic) }\end{array}$ \\
\hline $\begin{array}{l}\text { Communication of } \\
\text { goals and objectives }\end{array}$ & $\begin{array}{l}\text { The teacher formulates and } \\
\text { communicates to the students } \\
\text { what to learn. The main goal of } \\
\text { the teacher is to do what is } \\
\text { planned. }\end{array}$ & $\begin{array}{l}\text { Students themselves formulate, } \\
\text { defining the boundaries of } \\
\text { knowledge and ignorance } \\
\text { according to the scheme "remember } \\
\rightarrow \text { learn } \rightarrow \text { learn" (the teacher leads } \\
\text { students to the realization of goals } \\
\text { and objectives) }\end{array}$ \\
\hline Planning & $\begin{array}{l}\text { The teacher tells them what } \\
\text { work they do to achieve the goal. }\end{array}$ & $\begin{array}{l}\text { Planning by students of ways to } \\
\text { achieve the intended goal (the } \\
\text { teacher helps, advises) }\end{array}$ \\
\hline $\begin{array}{l}\text { Practical activity of } \\
\text { students }\end{array}$ & $\begin{array}{l}\text { Under the guidance of a teacher, } \\
\text { students perform a number of } \\
\text { practical tasks (the frontal } \\
\text { method of organizing activities } \\
\text { is more often used) }\end{array}$ & $\begin{array}{l}\text { Students carry out educational } \\
\text { activities according to the planned } \\
\text { plan (group, individual methods are } \\
\text { used), the teacher advises }\end{array}$ \\
\hline Exercise control & $\begin{array}{l}\text { The teacher monitors the } \\
\text { implementation of practical } \\
\text { work by students }\end{array}$ & $\begin{array}{l}\text { Students exercise control (forms of } \\
\text { self-control, mutual control are } \\
\text { used), the teacher advises }\end{array}$ \\
\hline Correction & $\begin{array}{l}\text { The teacher, in the course of } \\
\text { performing and following the } \\
\text { results of the work performed by } \\
\text { the students, carries out } \\
\text { correction }\end{array}$ & $\begin{array}{l}\text { Students formulate difficulties and } \\
\text { carry out correction on their own, } \\
\text { the teacher advises, advises, helps }\end{array}$ \\
\hline Assessment of learners & $\begin{array}{l}\text { The teacher evaluates the work } \\
\text { of students in the lesson }\end{array}$ & $\begin{array}{l}\text { Students assess the performance } \\
\text { according to its results (self- } \\
\text { assessment, assessment of the } \\
\text { results of the activities of } \\
\text { comrades), the teacher advises }\end{array}$ \\
\hline Lesson summary & $\begin{array}{l}\text { The teacher asks the students } \\
\text { what they have memorized }\end{array}$ & Reflection is carried out \\
\hline Homework & $\begin{array}{l}\text { The teacher announces and } \\
\text { comments (more often - the task } \\
\text { is one for everyone) }\end{array}$ & $\begin{array}{l}\text { Students can choose an assignment } \\
\text { from those suggested by the } \\
\text { teacher, taking into account their } \\
\text { individual capabilities }\end{array}$ \\
\hline
\end{tabular}

At each stage of the lesson, various universal educational actions are purposefully formed:

1. Motivation for learning activities. What does it mean to motivate a student to learn? First, it is necessary to update the requirements for it from the side of educational activities, i.e. his duties as a participant in the educational process ("must"); secondly, to create conditions for necessity to become an internal need ("I want"); thirdly, the student must be given confidence that he is able to solve the problems that arise in the learning process ("I can"). 
2. Creation of a problematic situation. A problem situation as a lesson stage is organized to prepare students for the discovery of new knowledge. Student perform the proposed learning action, actualizing the methods of action known to them, and note the difficulties associated with this work. The task should be interesting to the student, captivate him. The desire to explore something arises only when the object attracts, surprises, arouses interest. The theme should be original, it needs an element of surprise, unusualness. Originality in this case should be understood as the ability to look outside the box at traditional, familiar objects and phenomena. This rule is focused on the development of the most important characteristic of a creative person - the ability to see problems. The ability to find unusual, original points of view on different, including well-known objects and phenomena, distinguishes a true creator from a mediocre, creatively undeveloped person. The wording of the assignment should be such that the work is completed relatively quickly. At this stage, cognitive logical educational actions are formed: analysis, synthesis, comparison, generalization, analogy, classification, serialization, as well as the ability to extract the necessary information from various sources, to build a speech utterance. Regulatory actions are formed when students record an individual difficulty in a trial action. In the process of communication, students need to express their opinion with sufficient completeness and accuracy, argue it, take into account other opinions.

3. Identification of the cause of the difficulty. In order to understand why a difficulty arose during the execution of a test task, students must restore the performed operations, fix the place a step, an operation - where the difficulty arose; then, on this basis, identify the cause of the difficulty - those specific knowledge, skills that are lacking to solve a test task and problems of this type in general. At this stage, the following are formed: analysis, synthesis, comparison, generalization, analogy, summing up a concept, defining basic and secondary information, posing and formulating a problem; expressing one's thoughts with sufficient completeness and accuracy, arguing one's opinion and position in communication, taking into account different opinions, coordinating different positions, resolving conflicts (communicative).

4. Search for ways to resolve the problem. At this stage, students set a goal, choose a method and plan to achieve the goal, determine the means, resources and terms. This process is guided by the teacher: first with the help of a leading dialogue, then with an encouraging dialogue, and then the children independently carry out research. This stage is the most important for the formation of universal educational actions: self-determination and meaning formation takes place. Along with the already listed cognitive and regulatory actions, such as the search and selection of the necessary information, the choice of the most effective ways to solve problems, the independent selection and formulation of a cognitive goal, planning, forecasting, and structuring of knowledge are formed.

5. Implementation of the plan for resolving the arisen difficulty. Students offer different options for action, which are discussed by all members of the group, and then the most effective is selected. This decision is fixed in external speech and / or in the form of a diagram (symbolic). This method of action is used to solve the original problem that caused the difficulty. As a result, the difficulty must be overcome, which is also recorded. This activity forms the ability to be aware of responsibility for a common cause, volitional self-regulation, cognitive initiative.

6. Checking the effectiveness of the found method of operation. Students solve common tasks using a new way of acting. This work can be done in pairs, in groups, or frontally.

7. Independent work and self-test. At this stage, students work independently: they perform tasks of a new type, carry out their self-examination, step by step comparing with the standard, identify and correct their own mistakes.

8. Reflection and self-esteem. At this stage, the new content studied in the lesson is fixed, and reflection and self-assessment by students of their own educational activities is organized. This means that students must correlate the goal of educational activity and its results, fix the degree of their relevance and outline the goals of further activity. At this stage, universal 
educational actions are formed that allow one to evaluate one's own activity: reflection of the methods and conditions of action, control and assessment of the process and results of activity, self-assessment based on the criterion of success, an adequate understanding of the reasons for success / failure in educational activity.

In conclusion I want to say that classes organized on the basis of a meta-subject approach, also use modern educational technologies in the educational process: technology for the development of critical thinking, problem learning, project learning, etc., which will provide the student with general cultural, personal and cognitive development, equip with the ability to learn. The teacher must be ready for improvisation (for changes and correction of the "course of the lesson" in the course of its conduct).

\section{REFERENCES:}

Common European framework of reference for languages. Cambridge Assessment English. Retrieved from: https://www.cambridgeenglish.org/exams-and-tests/cefr

Galyan, S. V. (2014). Meta-subject approach in teaching schoolchildren: Methodological recommendations for teachers of secondary schools.

Khutorskoy, A. V. (2012). Meta-subject content and results of education: How to implement Federal state educational standards (FSES). Eidos, 1.

Kraevsky, V. V., \& Khutorskoy, A. V. (2003). Subject and general subject in educational standards. Pedagogy, 2, 3-10.

Krichevets, A. N. (2012). The transcendental subject and the diversity of cognitive frameworks. Russian Studies in Philosophy, 50(4), 43-55. Available at: https://doi.org/10.2753/RSP10611967500403.

Duong, T. K. O. (2019). Integrating competence-based assessment into instruction pedagogical subjects for developing core competences of technical and vocational education students at Ho Chi Minh City University of technology and education. Universal Journal of Educational Research, 7(10), 2045-2056.Available at: http://dx.doi.org/10.13189/ujer.2019.071002 